\title{
Corrigendum: Mediterranean Sea: A Failure of the European Fisheries Management System
}

\author{
Frontiers Editorial Office* \\ Frontiers Media S.A., Lausanne, Switzerland
}

Keywords: Mediterranean, common fishery policy, management, effort, failure

\section{OPEN ACCESS}

Edited and reviewed by: Frontiers in Marine Science Editorial

Office,

Frontiers, Switzerland

*Correspondence:

Frontiers Editorial Office editorial.office@frontiersin.org

Specialty section:

This article was submitted to Marine Affairs and Policy,

a section of the journal Frontiers in Marine Science

Received: 25 April 2018 Accepted: 26 April 2018

Published: 04 June 2018

Citation: Frontiers Editorial Office (2018) Corrigendum: Mediterranean Sea: A Failure of the European Fisheries

Management System

Front. Mar. Sci. 5:169.

doi: 10.3389/fmars.2018.00169

\section{A commentary on}

Mediterranean Sea: A Failure of the European Fisheries Management System

by Cardinale, M., and Scarcella, G. (2017). Front. Mar. Sci. 4:72. doi: 10.3389/fmars.2017.00072

Following an investigation by the European Commission's Joint Research Center, it was found that Dr. Giacomo Chato Osio meets the criteria to be listed as an author on this manuscript. The authorship list is therefore updated to be:

Massimiliano Cardinale ${ }^{1 *}$, Giacomo Chato Osio ${ }^{2}$ and Giuseppe Scarcella ${ }^{3}$

${ }^{1}$ Department of Aquatic Resources, Marine Research Institute, Swedish University of Agricultural Sciences, Lysekil, Sweden

${ }^{2}$ Directorate D - Sustainable Resources, Unit D.02 Water and Marine Resources, European Commission Joint Research Centre (JRC), Ispra, Italy

${ }^{3}$ Institute of Marine Sciences of the Italian National Research Council, Ancona, Italy

e-mail:giacomo-chato.osio@ec.europa.eu

The original article has been updated.

Conflict of Interest Statement: The authors declare that the research was conducted in the absence of any commercial or financial relationships that could be construed as a potential conflict of interest.

Copyright () 2018 Frontiers Editorial Office. This is an open-access article distributed under the terms of the Creative Commons Attribution License (CC BY). The use, distribution or reproduction in other forums is permitted, provided the original author(s) and the copyright owner are credited and that the original publication in this journal is cited, in accordance with accepted academic practice. No use, distribution or reproduction is permitted which does not comply with these terms. 